\title{
Genetic Structure of Peruvian Populations of Phytophthora infestans
}

\author{
Willmer G. Perez, J. Soledad Gamboa, Yesenia V. Falcon, Mario Coca, Rubi M. Raymundo, and Rebecca J. Nelson
}

International Potato Center (CIP), Lima 12, Peru.

Current address of M. Coca: Universidad Mayor de San Andres, La Paz, Bolivia.

Current address of R. Nelson: 322 Plant Science, Cornell University, Ithaca, NY 14853.

Accepted for publication 25 June 2001.

\begin{abstract}
Perez, W. G., Gamboa, J. S., Falcon, Y. V., Coca, M., Raymundo, R. M., and Nelson, R. J. 2001. Genetic structure of Peruvian populations of Phytophthora infestans. Phytopathology 91:956-965.

Isolates of the late blight pathogen Phytophthora infestans $(n=327)$ from the central to southern Peruvian Andes were systematically collected in 1997 to 1999 and analyzed to determine the pathogen's population structure at its host's center of diversity. No isolates of the A2 mating type were detected. Cluster analysis of DNA fingerprinting data indicated that the collection consisted of five major groups that were interpreted to be clonal lineages. Two of the lineages (US-1 and EC-1) have been previously described, and three (PE-3, 5, and 6) are described here for the first time. Collections from three areas in the central Peruvian Andes,
\end{abstract}

ABSTRACT

Peruvian populations of the oomycete pathogen Phytophthora infestans, which causes late blight of potato (Solanum tuberosum) and other solanaceous species, are of interest for both practical and historical reasons. Potato breeding lines used by national programs in many developing countries are selected in Peru for late blight resistance through exposure to Peruvian isolates and field populations of $P$. infestans. It is thus important to an international breeding effort to analyze these isolates and populations in the context of pathogen populations present elsewhere.

The Peruvian and Bolivian Andes are considered to be the potato's center of diversity, and the region is rich in biodiversity for the many solanaceous hosts of $P$. infestans (24). The relatively high host diversity in the region may affect the population structure and evolution of the pathogen. In potato production areas where diverse traditional varieties are still in use, pathogen diversity might be expected to be high (46). Systematic studies of pathogen diversity have not been conducted in the southern Peruvian Andes where potato diversity is richest.

Forbes et al. (9) noted that there is a risk of sexual reproduction of the pathogen in potato production zones near the border between Peru and Bolivia because populations of $P$. infestans documented in Peru have the A1 mating type (41), whereas those collected from Bolivia have the A2 mating type (15). Although recombination and migration among $P$. infestans populations could lead to increased hazards both for potato producers and for plant genetic resources in the Andes, it could also lead to identification of useful screening sites for the potato resistance breeding program.

Analysis of Peruvian pathogen populations can also shed light on the migratory trajectory that led to the Irish potato famine. The Toluca Valley of Mexico is recognized as the center of diversity

Corresponding author: R. J. Nelson; E-mail address: r.nelson@cgiar.org

Publication no. P-2001-0816-03R

(c) 2001 The American Phytopathological Society including two key sites used in an international potato breeding program, consisted of isolates of the EC-1 lineage, which has been reported to dominate the pathogen population in Andean countries to the north of Peru. The collections from Cusco and Puno were more diverse. More than one lineage was detected in 10 of the 20 fields sampled in Cusco. Data on virulence, metalaxyl sensitivity, and band data for allozymes, mitochondrial DNA, and ipiB1 suggested that PE-3 may have been produced through recombination events between US-1 and EC-1. Restriction fragment length polymorphism and amplified fragment length polymorphism marker data were not consistent with this hypothesis.

Additional keywords: differentiation, Irish famine pathogen, oomycete, Solanaceae. for the pathogen. $P$. infestans is believed to have been dispersed from Toluca through two major migrations (11). The first of these, which is postulated to have occurred in the 19th century, is believed to have led to the worldwide dissemination of a single clonal lineage of the pathogen, designated US-1 (15). Some authors have interpreted historical evidence as suggesting that late blight may have existed in the Andes prior to the recognized waves of migration of the pathogens $(1,3,41)$, presumably as the result of an ancient migration from Mexico. Late blight resistance detected in Andean potato species is considered to be consistent with this idea $(23,33$; W. Pérex, A. Salas, R. Raymundo, Z. Haumán, R. Nelson, and M. Bonierbale, unpublished data).

Andrivon (3) argued that available data are most consistent with a three-step migration. According to this hypothesis, $P$. infestans migrated from Mexico to the South American Andes some centuries ago, resulting in the fixation of the US-1 lineage there. Migrations from the Andes to North America and then to Europe in the 1840s, perhaps associated with the guano boom and through traffic in potato genetic resources, are proposed to have led to the Irish famine and to the generalized spread of the US-1 clonal lineage. Identification of relatively high levels of diversity among Peruvian isolates of the US-1 lineage might be considered to support to this hypothesis.

Ristaino et al. (37) recently analyzed a mitochondrial DNA (mtDNA) fragment from $P$. infestans specimens taken from historical herbarium samples collected around the time of the Irish potato famine. Surprisingly, the DNA sequence of the mtDNA fragment analyzed was different from that of the US-1 lineage, which has been believed to have been responsible for the late blight epidemics of the 1840 s.

In spite of the published debate, relatively little is known about contemporary populations of $P$. infestans in Peru. Available data, however, suggest surprising levels of diversity within US-1. The only published reports are based on a set of 34 isolates collected from the central Peruvian highlands in the mid-1980s $(19,41)$. The 1,776 entries in a global marker database of $P$. infestans include 
only 45 Peruvian isolates, which were collected between 1982 and 1986. Forbes et al. (10) reported that Peru and the United States shared two of the seven genotypes of the US-1 lineage documented in the database. Goodwin et al. (19) reported four US-1 genotypes among 25 Peruvian isolates collected in 1984 to 1985: three of these were shared with U.S. populations and one was unique to Peru. Among the four mitochondrial haplotypes obtained by restriction analysis using EcoRI for an international collection of $>140$ isolates, three were found among 15 Peruvian isolates and three were found among 74 isolates from Mexico. One haplotype was unique to Peru (13).

The present study was undertaken to characterize populations of $P$. infestans infecting potato in the southern Peruvian Andes. Four specific hypotheses were tested. The first and most general hypothesis was that Peruvian pathogen populations have changed substantially since the study of Tooley et al. (41), and had acquired the characteristic features of the "new" P. infestans populations present in many countries (broad-spectrum virulence and resistance to metalaxyl) through processes of migration or recombination. This was suggested by anecdotal evidence of farmers' increased difficulties in managing the disease, and would be consistent with global trends in late blight (11).

The two screening sites used by the International Potato Center's (CIP's) late blight breeding program were of particular interest in this regard. Effective evaluation of quantitative resistance requires that major genes be readily overcome; this would be most likely for a pathogen population with broad spectrum and diverse virulence phenotypes. The pathogen population at breeders' screening sites should ideally reflect trends in pathogen populations in the regions that are served by the breeding program. Characterization of pathogen isolates from the two screening sites at Comas and Oxapampa, therefore, included analyses of virulence as well as of molecular markers. Data on virulence and metalaxyl reaction were obtained for samples of the broader collections with the hope of providing insights that would be useful for disease management in Peru.

The second hypothesis was that the A1 and A2 mating types meet in southern Peru (the "sexual frontier" hypothesis). The original US-1 clonal lineage, or the EC-1 clonal lineage that displaced US-1 in Ecuador, was hypothesized to encounter the A2 lineage known to occur in Bolivia. To test this hypothesis, systematic and relatively intensive sampling was conducted in the states or "departments" of Cuzco and Puno.

The third hypothesis was that pathogen diversity would be relatively high in southern Peru. This was of interest in light of questions regarding the role of Peruvian pathogen populations in the historical migrations of $P$. infestans $(3,37)$. Analysis of the collections from southern Peru was considered appropriate for testing this hypothesis because the relatively high potato diversity in this area might be likely to maintain accumulated diversity. The fourth hypothesis was that the Peruvian lineage PE-3 was formed by parasexual recombination involving US-1 and EC-1; this hypothesis emerged during the course of the study.

TABLE 1. Geographical distribution of Peruvian isolates analyzed by Tooley et al. (41) and analyzed in the present study

\begin{tabular}{lcc}
\hline Department $^{\mathrm{a}}$ & $\begin{array}{c}\text { No. of isolates analyzed } \\
\text { by Tooley et al. }\end{array}$ & $\begin{array}{c}\text { No. of isolates analyzed } \\
\text { in present study }\end{array}$ \\
\hline Huanuco & 8 & 7 \\
Pasco & 6 & 47 \\
Junin & 20 & 75 \\
Cusco & 0 & 112 \\
Puno & 0 & 85 \\
\hline
\end{tabular}

${ }^{a}$ Departments are the Peruvian equivalents of states in the United States.

b Analyzed for mating type, virulence (pathotype), nuclear DNA content, and isozymes by Tooley et al. (41). A subset of these isolates was later analyzed by restriction fragment length polymorphism using the probe RG57 (19).

\section{MATERIALS AND METHODS}

Sampling. Different sampling strategies were used for different regions, according to the objectives of the study. For the two southernmost departments of Peru (Puno and Cusco, sampled February to March 1997), a relatively wide area was sampled using a stratified strategy designed at allow analysis of diversity within and between fields, sites, and regions. For each department (the Peruvian equivalent of a state), several localities (neighboring villages) were sampled. For each locality (defined by the nearest settlement), three or four fields were sampled, with 10 samples taken per field unless very low levels of disease limited the number of lesions found. The specific sampling route was based on maps constructed using geographic information systems, indicating zones of high estimated late blight severity.

For the departments of Pasco and Junin, the objectives were more limited; the sampling strategy was designed to allow assessment of the dominant pathogen genotypes at two sites in the central highlands of Peru (Comas and Oxapampa) used in CIP's late blight breeding program. For this purpose, 45 samples were taken from Oxapampa (in the department of Pasco; sampled from October to November 1997 and March 1998) and 75 samples were taken from Comas (in the department of Junin; sampled in 1997 to 1998). Each infected leaflet was maintained after collection in a sealed petri dish containing a layer of $1.5 \%$ water agar. Using this method, infected tissue could be maintained for 7 to 10 days between collection in the field and isolation in the laboratory.

In addition to the main sample sets mentioned above, additional small groups of isolates were included in the analysis to allow a broader comparison of contemporary collections with those analyzed by Tooley et al. (41) (Table 1): isolates from Tarma, Junin ( $n=9$; collected on eight dates between 1989 to 1999); the Mantaro Valley, Junin ( $n=2$; collected in February and March 1998); Mayobamba, Huanuco ( $n=7$; collected in November and September 1996); and Paucartambo, Pasco ( $n=6$; collected on five dates in 1998 and 1999).

A small group of available Peruvian isolates collected between 1984 and 1995 ( $n=12$; listed in Table 2) were used for direct comparison of collections from different periods. Samples of lyophilized, nonviable mycelium of a small number of $P$. infestans isolates from the United States $(n=3)$, Ecuador $(n=2)$, and Argentina $(n=1)$ were used for international comparisons (Table 2; provided by G. Forbes of CIP-Quito and W. Fry of Cornell University).

Pathogen isolation, culture, and storage. Upon return from the field, plates with infected tissue were incubated for 0 to 5 days at 15 to $18^{\circ} \mathrm{C}$ to promote sporulation. Sporangia were collected on

TABLE 2. Reference isolates used for lineage comparisons (DNA band profiles) in this study

\begin{tabular}{lcccc}
\hline Isolate code & Lineage & $\begin{array}{c}\text { Year of } \\
\text { collection }\end{array}$ & $\begin{array}{c}\text { Location of } \\
\text { collection }\end{array}$ & $\begin{array}{c}\text { Mating } \\
\text { type }\end{array}$ \\
\hline PE 84006 & US-1 & 1984 & Junin, Peru & A1 \\
PE 840028 & US-1 & 1984 & Junin, Peru & A1 \\
PE 850019 & US-1 & 1985 & Junin, Peru & A1 \\
228 & US-1.c & 1985 & Junin, Peru & A1 \\
1411 & US-1.d & 1994 & Apurimac, Peru & A1 \\
1394 & EC-1 & 1994 & Junin, Peru & A1 \\
1385 & EC-1 & 1994 & Junin, Peru & A1 \\
PE 96005 & EC-1 & 1994 & Junin, Peru & A1 \\
1431 & EC-1.1 & 1994 & Cajamarca, Peru & A1 \\
1452 & PE-3 & 1994 & Junin, Peru & A1 \\
1393 & PE-3 & 1994 & Junin, Peru & A1 \\
1696 & PE-3 & 1995 & Arequipa, Peru & A1 \\
1021 & EC-1 & 1993 & Ecuador & A1 \\
2939 & EC-2 & 1996 & Ecuador & A2 \\
1473 & BR-1 & 1996 & Argentina & A2 \\
- & US-1 & 1984 & USA & A1 \\
- & US-7 & 1994 & USA & A2 \\
- & US-8 & 1994 & USA & A2 \\
\hline
\end{tabular}


a $10-\mu \mathrm{m}$ filter and rinsed with water. The filter system allowed efficient recovery of isolates even when the infected tissue was several days old and contaminated with bacteria and saprophytes. The sporangial suspension was refrigerated at 5 to $8^{\circ} \mathrm{C}$ to promote the liberation of zoospores. Potato tuber slices (var. Huayro) were inoculated with $20 \mu \mathrm{l}$ of the zoospore suspension per slice and incubated at $18^{\circ} \mathrm{C}$ for 5 to 7 days in moist chambers. Mycelial fragments were transferred aseptically to Rye B agar and V8 agar plates. After 1 to 2 weeks, growing colonies were transferred to Rye A agar and maintained at $15^{\circ} \mathrm{C}$.

Mating type. Complete testing of mating type by conventional pairing was not possible in Peru because A2 test isolates were not available. No Peruvian isolates with the A2 mating type had been reported, and importation was undesirable for quarantine reasons. Therefore, three types of evidence were used to infer the likely mating type of the Peruvian collections. The first approach was to pair a set of isolates $(n=327)$ with two isolates of known A1 mating type (Peruvian isolates 228 and 1696) on $10 \%$ clarified V8 agar. Plates were placed in an incubator at $15^{\circ} \mathrm{C}$ in the dark and examined for the presence of oospores after 4 weeks. The second approach was to test for a marker linked to the mating-type locus using a polymerase chain reaction (PCR)-based assay (25); this method was used for a subset of 96 of the isolates, representing the available diversity as indicated by available passport (collection site) and characterization data (RG57 genotype). The third approach was to evaluate the DNA fingerprints of the isolates (most of the isolates were identified as belonging to known lineages that had been characterized in previous reports).

Virulence assays. The specific virulence of 95 isolates was determined by inoculation of detached leaflets of a differential set of potato cultivars carrying the 11 known major (R) genes for resistance. Each virulence assay was repeated at least twice. Differentials were obtained from the Research Institute for Plant Protection, Wageningen, the Netherlands: R1 (CEBECO-43154-5; CIP 800986), R2 (CEBECO-44158-4; CIP 800987), R3 (CEBECO4642-1; CIP 800988), R4 (CEBECO-4431-5; CIP 800989), R5 (Black 3053-18; CIP 800990), R6 (Black XD2-21; CIP 800991), R7 (Black 2182ef(7); CIP 800992), R8 (Black 2424a(5); CIP 800993), R9 (Black 2573; CIP 800994), R10 (Black 3618ad(1); CIP 800995), and R11 (Black 5008ab(6); CIP 800996). In each experiment, at least one susceptible local variety was included as a control.

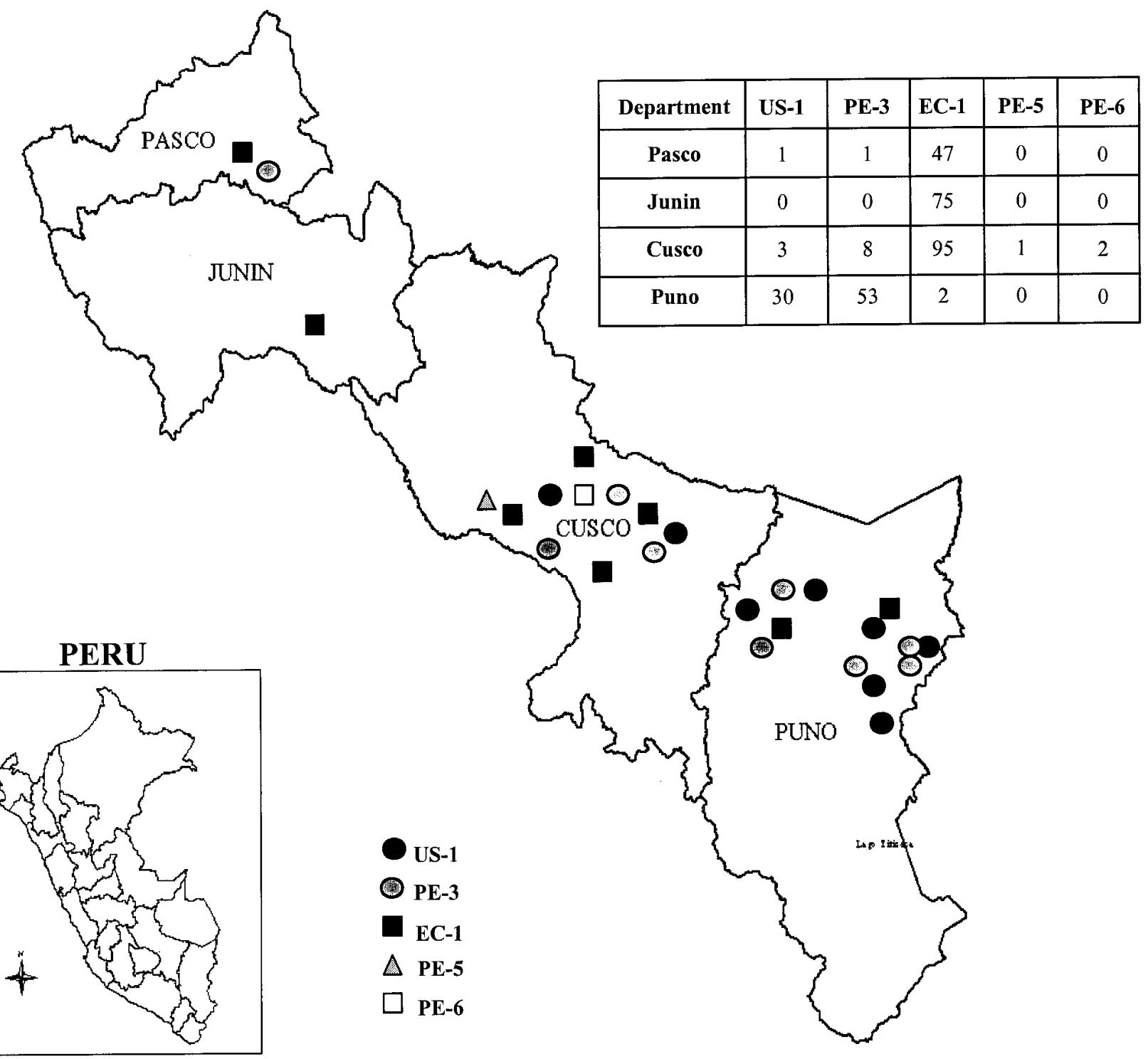

Fig. 1. Geographical distribution of Phytophthora infestans lineages detected in this study. The four Peruvian departments sampled are shown in the map at center (a department in Peru is the equivalent of a state in the United States). The inset map of Peru at bottom left shows the location of the four departments sampled (shaded) in relation to the rest of Peru. The inset table at top right shows the numbers of isolates of each lineage (defined by restriction fragment length polymorphism by the probe RG57) that were detected in each department. 
For confirmation, 10 isolates were retested on differentials obtained from the Scottish Crop Research Institute, Scotland: R1 (Craig's White Snow; CIP 801039), R2 (15152(16); CIP 801040), R3 (Pentland Ace; CIP 801041), R4 (1563c(14); CIP 801042), R5 (3053-18; CIP 801043), R6 (XD2-21; CIP 801044), R7 (2182ef(7); CIP 801045), R8 (2424a(5); CIP 801046), R10 (3681ad(1); CIP 801047), R11 (5008ab(6); CIP 801048), and a line not known to carry R genes (Craig's Royal; CIP 801038).

Inoculum for virulence tests was obtained from tuber slices incubated for 6 to 7 days at $18^{\circ} \mathrm{C}$ in a moist chamber. Leaflets collected from the middle part of each differential cultivar at 45 to 60 days of age were inoculated in inverted petri dishes lined with $1.5 \%$ agar water, such that leaflets lay in the lids below the agar layer. A $20-\mu \mathrm{l}$ drop of sporangia (approximately $5 \times 10^{3}$ sporangia per $\mathrm{ml}$ ) was placed on the abaxial surface of each leaflet. Each test included susceptible cv. Chata Blanca (containing no known $\mathrm{R}$ genes) as a control.

Metalaxyl resistance. A subset $(n=322)$ of isolates was plated on $10 \%$ V8 agar containing metalaxyl at concentrations of 0,5 , 50 , and $100 \mathrm{ppm}$. A plug of mycelium was placed in the center of the plate, and plates were incubated in darkness at $18^{\circ} \mathrm{C}$ for 15 days before radial growth was measured (22). Isolates were considered resistant to the systemic fungicide if growth did not reach $40 \%$ of the 0 -ppm control at any metalaxyl concentration. Isolates were considered moderately resistant if growth was reduced to $<40 \%$ of the control value at $100 \mathrm{ppm}$, but not at $5 \mathrm{ppm}$. Isolates were considered sensitive if growth was retarded at $5 \mathrm{ppm}$ to $<40 \%$ of the 0 -ppm control $(5,28,40)$.

Allozyme analysis. A subset of 87 isolates was analyzed for their glucose-6-phosphate isomerase (Gpi) or peptidase (Pep) genotypes using three electrophoretic procedures according to published protocols. Either fresh or lyophilized mycelium was used for allozyme analysis. Cellulose acetate electrophoresis (CAE) allowed differentiation of Gpi genotypes 86/100 and 100/100 (17), whereas starch gel electrophoresis (39) permitted identification of the Gpi genotypes 86/100, 90/100, and 100/100. CAE allowed differentiation of Pep genotypes $92 / 100$ and 100/100, whereas polyacrylamide gel electrophoresis (PAGE) allowed resolution of Pep genotypes 92/100, 96/100, and 100/100 (45).

Isolation of DNA. Cultures of $P$. infestans were grown in pea broth (filtrate from $120 \mathrm{~g}$ of autoclaved frozen peas per liter) in disposable petri dishes at $18^{\circ} \mathrm{C}$ in a dark incubator without shaking. For each isolate, five to six petri dishes were inoculated with mycelium from an actively growing colony in Rye B agar. After 10 days, the fungal tissue was harvested by vacuum filtration, frozen at $-70^{\circ} \mathrm{C}$ for several hours, and lyophilized for 4 to 5 days. Lyophilized tissue was ground in liquid nitrogen, and DNA was extracted from the powdered mycelium (6).

PCR. A subset of the isolates from Puno and Cuzco $(n=96)$ was analyzed by PCR using the primers S1A and S1B as described by Judelson (25). These primers amplify a fragment of DNA of approximately $1,250 \mathrm{bp}$ corresponding to locus S1, which is linked to the A1-determining allele of the mating-type locus. It represents a tandemly repeated array of DNA elements that is typically present in a hemizygous state in A1 isolates but is absent in A2 isolates (25). DNA from A1 and A2 mating-type isolates and no-template controls were included in each assay.

A subset $(n=87)$ of the isolate collection was analyzed for mitochondrial haplotypes using PCR protocols described elsewhere (20). Each DNA sample was amplified with four combinations of the following primer pairs: P1 (P1f: 5'-GCAATGGGTAAATCGGCTCAA-3'; P1r: 5'-AAACCATAAGGACCACACAT-3'), P2 (P2f: 5'-TTCCCTTTGTCCTCTACC GAT-3'; P2rb: 5'-TTACGGCGGTTTAGCACATACA-3'), P3 (P3f: 5'-ATGGTAGAGCGTGGGAATCAT-3'; P3r: 5'-AATACCGCCTTTGGGTCCATT-3'), and P4 (P4f: 5'-TGGTCATCCAGAGGTTTATGTT-3'; P4r: 5'CCGATACCGATACCAGCACCAA- $\left.3^{\prime}\right)$. Amplified fragments were digested with $C f o \mathrm{I}$ (for P1), MspI (for P2), EcoRI (for P3), and $E c o$ RI (for P4). The resulting restriction fragments were separated on $2 \%$ agarose gels and visualized by staining with ethidium bromide.

Five genes highly expressed in $P$. infestans during the infection process were assayed by PCR: ipiB1 "in planta-induced" (43), ricl (44), niaA (35), calA (36), and infl $(26,27)$. Primers were designed for these genes based on publicly available DNA sequence information. The primers sequences used were: ipiB1 (f: $5^{\prime}$ TGTTCAGCAGTAGCAAGATC-3'，r: 5'-ATGCGATAACCTGTCTGCTT-3'); ricl (f: 5'-CGGAGATATCCCTCGTCTGA-3', r: 5'-TTTGGCCCACTGCAACTGTC-3'); niaA (f: 5'-CATGACGCGTTTGAGATCTG-3', r: 5'-CGATTTCGGGATAACTCACA-3'); calA (f: 5'-CAGATTGCCGAGTTCAA-3', r: 5'-TGGTCATGATGTGACGCAG-3'); and infl (f: 5'-TGTTATCCCCACCCACTC-
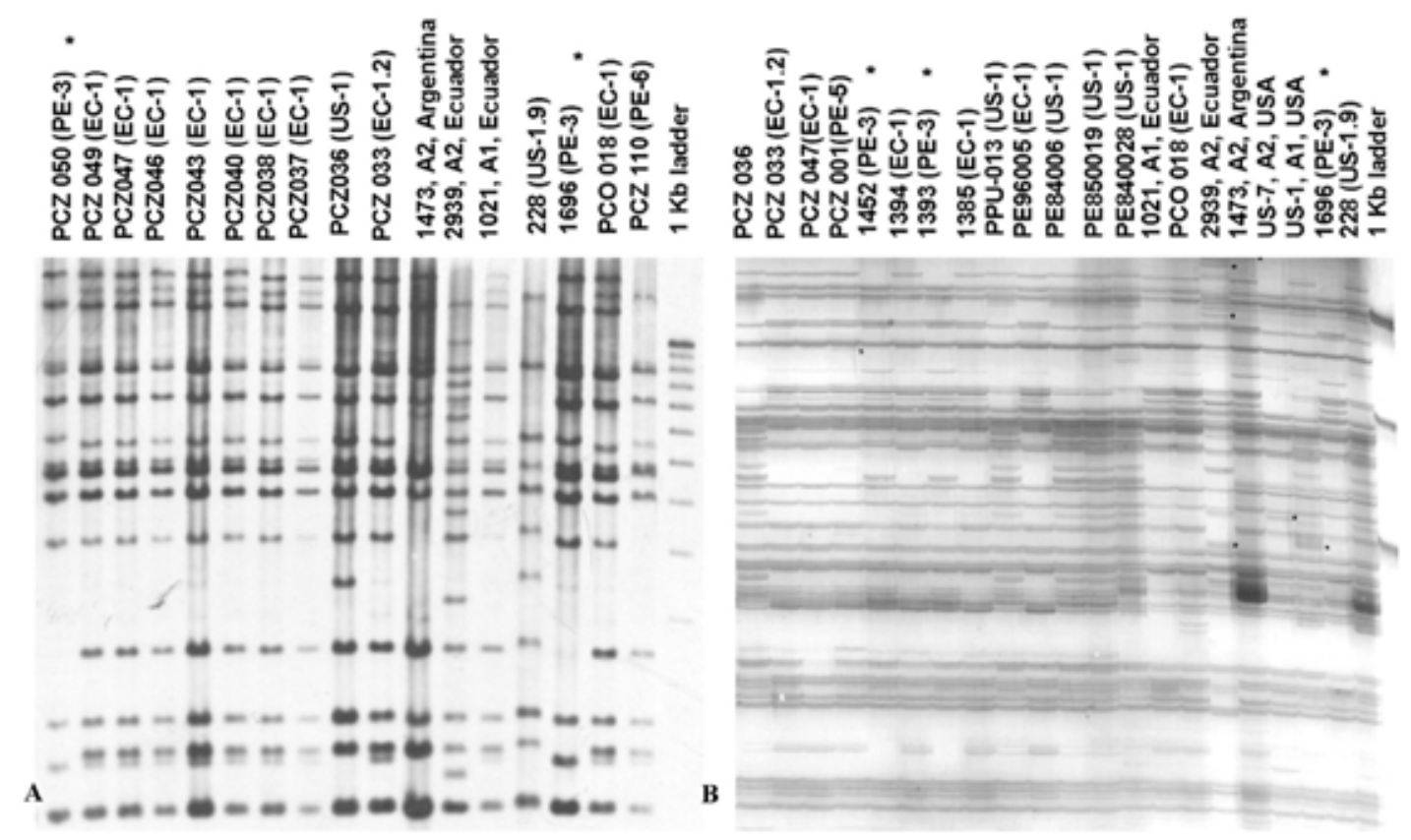

Fig. 2. DNA fingerprints of selected isolates showing PE-3 $(*)$ in relation to other genotypes. A, Restriction fragment length polymorphism patterns detected by enhanced chemiluminescence. $\mathbf{B}$, A portion of an amplified fragment length polymorphism gel with bands detected by silver staining. 
CT-3', r: 5'-CTCATAGCGACGCACACGTA-3'). The amplified products were digested with restriction enzymes chosen with the "Webcutter" program (available on-line from the University of Goteburg). The fragments obtained were separated by PAGE electrophoresis and visualized by silver staining.

Restriction fragment length polymorphism. DNA hybridization analysis was performed with the probe RG57 (16). Three micrograms of DNA from each isolate was digested with EcoRI. Hybridization and detection were done following the protocol of the ECL nonradioactive DNA detection kit (Enhanced Chemiluminescent Direct Nucleic Acid Labeling and Detection System; Amersham Pharmacia Biotech, Piscataway, NJ).

Amplified fragment length polymorphism. The amplified fragment length polymorphism (AFLP) assay was carried out according to a protocol established for P. infestans (42). The primary template was prepared in a one-step restriction-ligation reaction using the restriction enzymes EcoRI and MseI. The sequence of the primers used in the pre-amplification step was $\mathrm{E}+\mathrm{A}$ and $\mathrm{M}+\mathrm{A}$ (core sequences: $\mathrm{E}=5^{\prime}$-AGACTGCGTACC-

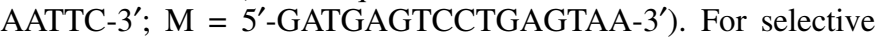
amplification, the secondary template DNA was amplified with primers containing two selective $3^{\prime}$ nucleotides. Three primer combinations were tested: $\mathrm{E}+\mathrm{AA}$ and $\mathrm{M}+\mathrm{AC}, \mathrm{E}+\mathrm{AC}$ and $\mathrm{E}+\mathrm{CA}$, and $\mathrm{E}+\mathrm{AA}$ and $\mathrm{M}+\mathrm{CA}$. Results were visualized by silver staining according to the manufacturer's manual (Promega, Madison, WI).

Estimates of diversity, complexity, and similarity. Diversity of the overall collection was estimated using Nei's formula (32):
$H=[n /(n-1)] \times\left(1-\Sigma X_{i}^{2}\right), i=1$; where $X_{i}$ is the frequency of the $i$ th genotype in the population, and $n$ is the number of isolates examined.

Diversity was estimated for each population with the Gleason and Shannon indices. The Gleason index was calculated as $H_{G}=$ $\left(n_{p}-1\right) / \ln \left(n_{i}\right)$, where $n_{p}$ is the number of races (or other variants) identified, and $n_{i}$ is the number of isolates tested (38). The Shannon index was calculated as $H_{S}=-\Sigma_{j}\left(p_{j} \times \ln \left(p_{j}\right), j=1 \ldots n_{p}\right.$, where $p_{j}$ is the frequency of the $i$ th race in the population, and $n_{p}$ is the number of races (38). The Gleason index reflects the richness of diversity (i.e., the number of different phenotypes present in the sample), whereas the Shannon index considers both richness and evenness (i.e., similarities of the frequencies of the different types) $(3,21,29,31)$. To reduce the biases introduced by differences in sample size, relative indices were calculated as follows: $H_{\mathrm{GR}}=$ $H_{G} / H_{G \max }=\left(n_{p}-1\right) /\left(n_{i}-1\right)$, and $H_{\mathrm{SR}}=H_{S} / H_{S \max }=\left(H_{S}\right) / \ln \left(n_{i}\right)$, where $H_{G \max }$ and $H_{S \max }$ are the greatest possible values of $H_{G}$ and $H_{S}$ in a sample of $n_{i}$ individuals. These maximal values are reached for $n_{p}=n_{i}$ (hence, $p_{j}=1 / n_{i}$, for all $\left.j s\right)$, and equal $H_{G \max }=\left(n_{i}-1\right) / \ln \left(n_{i}\right)$ and $H_{S \max }=\ln \left(n_{i}\right)$, respectively (2). The virulence complexity $(C)$ in the samples was calculated as both $C_{i}=\Sigma_{j}\left(p_{j} v_{j}\right), j=1 \ldots n_{p}$ and $C_{p}=(1 / n) \Sigma_{j} v_{j}, j=1 \ldots n_{p}$, where $v_{j}$ is the number of virulence genes of the $i$ th race, and $p_{j}$ and $n_{p}$ are as described previously (4). $C_{i}$ is the mean number of virulences per isolate, whereas $C_{p}$ represents the mean number of virulences per race.

Restriction fragment length polymorphism (RFLP) and AFLP fingerprints were scored visually for the presence or absence of

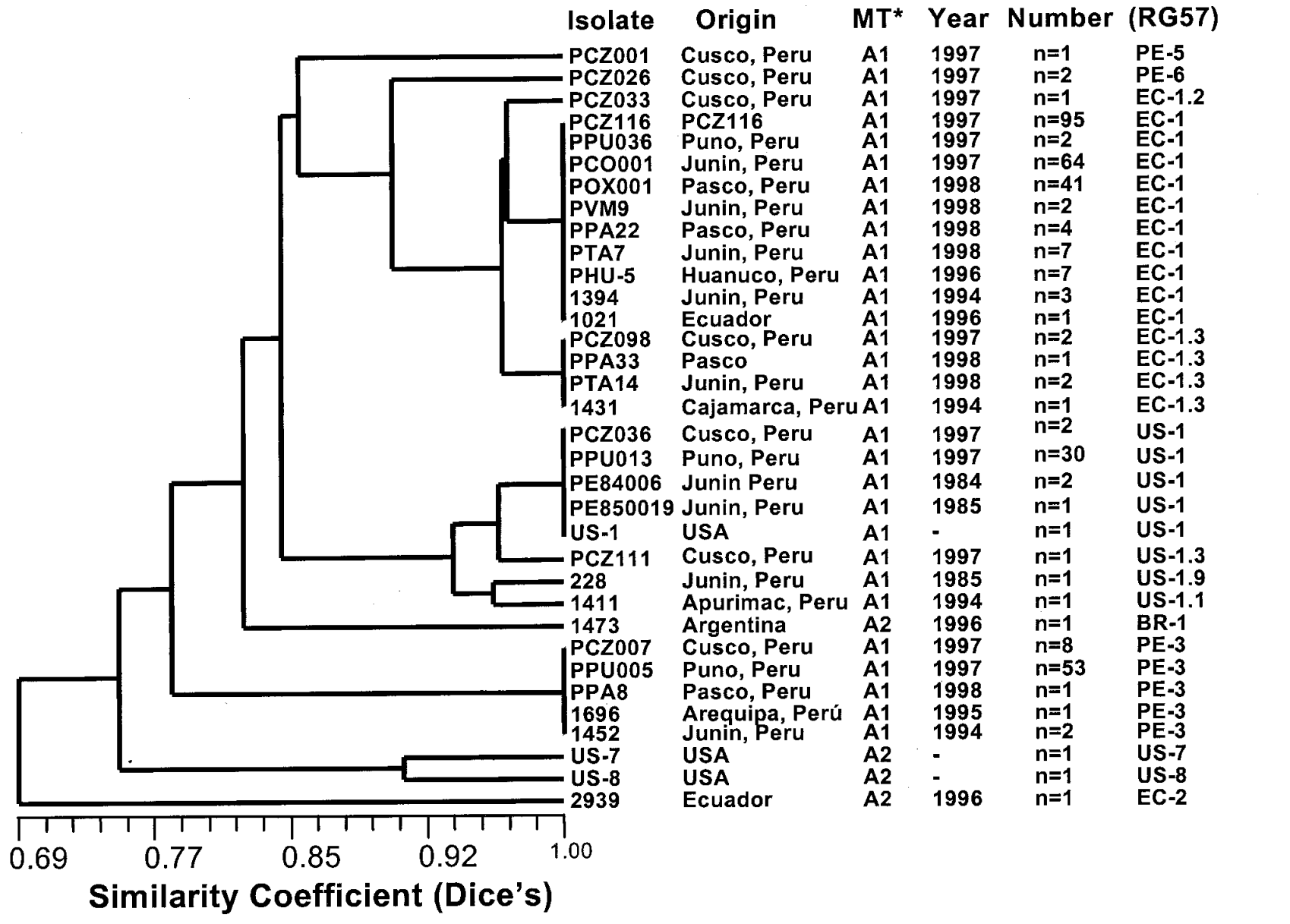

*Mating type

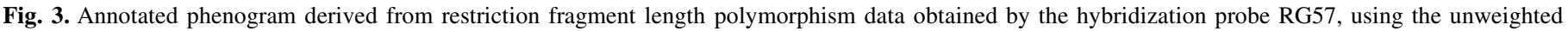
pair-group method with arithmetic mean algorithm. ${ }^{*} \mathrm{MT}=$ mating type inferred based on pairing in culture with two isolates of the A1 mating type. 
polymorphic DNA fragments. Cluster analysis was conducted using the unweighted pair-group method with arithmetic mean using the software program NTSYS-pc version 1.70 (Exeter Software, Setauket, NY). Similarity was calculated with Dice's coefficient (7).

\section{RESULTS}

Diversity and spatial differentiation. A total of 327 of the $P$. infestans isolates were analyzed by DNA fingerprinting with the RFLP probe RG57, and 98 of these were analyzed by AFLP fingerprinting. Eight genotypes were detected by RFLP, whereas 17 genotypes were defined by AFLP. Five lineages were defined based on cluster analysis of the RG57 band data. The geographical distribution of the lineages detected is shown in Figure 1. Representative DNA-banding profiles are shown in Figure 2, and an annotated phenogram derived from the RFLP data is shown in Figure 3. Two of the lineages (US-1 and EC-1) have been previously described, whereas three (PE-3, 5, and 6) are described here for the first time. Three of the twelve Peruvian reference isolates used (collected prior to the main collections reported here) showed the RG57 hybridization profile of PE-3; these isolates had been collected in 1994 and 1995 in Junin and Arequipa (on the southern Peruvian coast).

Three RG57-defined genotypes (US-1, EC-1, and PE-3) accounted for $97 \%$ of the collection. The lineage EC-1 was dominant in Pasco, Junin, and Cusco. Of the isolates analyzed by RFLP in this study, $70 \%$ belonged to the EC-1 lineage. The genotypes EC-1.2 and EC-1.3 (Fig. 3) were rare. The two isolates of
EC-1.2 were found in a single locality in Cusco, whereas the three isolates of EC-1.3 were distributed between two departments. Lineages US-1 and PE-3 were dominant in Puno. Although 100\% of the isolates collected in 1984 to 1986 were reported to be US-1 $(19,40)$, only $10 \%$ of the present collection belonged to this lineage.

The constitution and diversity of local collections varied sharply among the regions sampled. Using the RFLP data of the overall collection of 327 isolates, Nei's diversity index was $H=0.73$. For the collections from Huanuco and Junin, Nei's diversity index was $H=0$, because only the EC- 1 genotype was detected in these locations. For Pasco, the diversity index was $H=0.08$; the majority of isolates were of the EC-1 genotype and one PE-3 isolate was found. The set from Cusco had a diversity index of $H=0.27$, whereas the set from Puno had a diversity of $H=0.48$.

In many cases, multiple pathogen lineages were detected in single fields in Cusco and Puno. More than one genotype was detected in 10 of the 20 fields sampled in Cusco. In Paucartambo, Cusco, one field had lineages EC-1, PE-3, and PE-6, whereas another had US-1, EC-1, and PE-3. In Puno, EC-1 was rare $(3 / 85=3.5 \%$ of isolates for which RFLP data were obtained), whereas US- 1 and PE-3 were both common $(30 / 85=36 \%$ and $53 / 85=62 \%$ for US- 1 and PE-3, respectively). Both US-1 and PE-3 were collected from most fields in Puno, whereas one field had US-1, EC-1, and PE-3.

DNA extracts from 98 isolates, representing EC-1, EC-1.2, EC1.3, PE-3, and US-1, were analyzed by both RFLP and AFLP fingerprinting. In general, one-to-one correspondence was found for the major RFLP-defined groups (designated as lineages) and

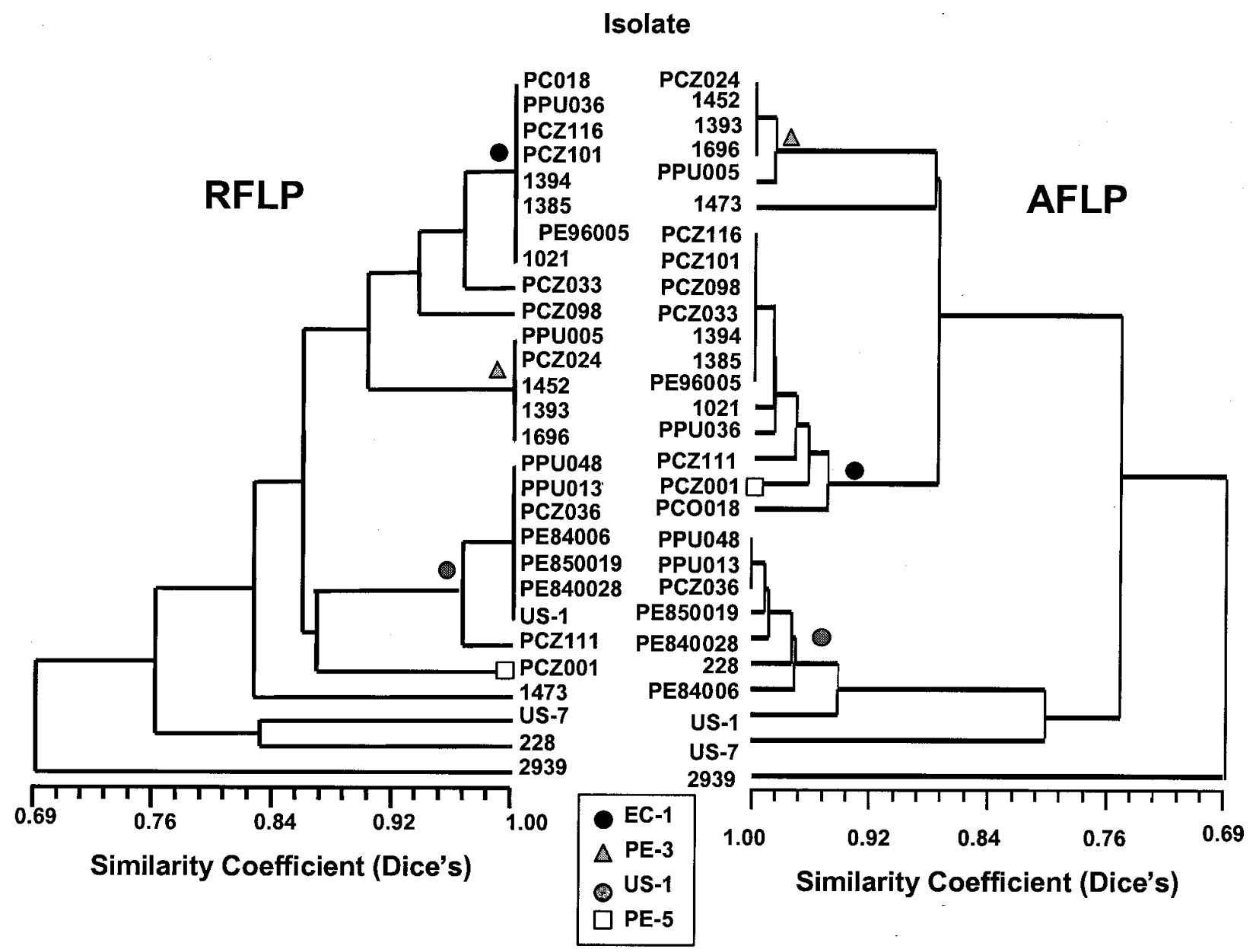

Fig. 4. Comparison of phenogram derived from restriction fragment length polymorphism (RFLP) analysis using the probe RG57 (left) and from amplified fragment length polymorphism (AFLP) fingerprinting (right). Symbols indicate the locations of comparable groups in the phenograms. 
the AFLP-defined groups. Such a correspondence was not found, however, at the level of genotypes within lineages (Fig. 4).

No evidence was found to support the hypothesis that the A1 and A2 mating types have met in southern Peru. None of the isolates $(n=327)$ collected in 1997 and 1999 from five contiguous departments spanning the central to southern Peruvian Andes (Huanuco, Pasco, Junin, Cusco, and Puno) formed abundant, typical oospores with either of the two A1 tester strains, indicating that they were not of the A2 mating type. The isolates were tentatively considered to belong to the A1 mating type.

Primers amplifying the S1 locus, which is linked to the $P$. infestans mating-type locus, were used to confirm this assignment for a subset of the isolates. For each of the 96 Peruvian isolates tested $(29 \%$ of the total collection, selected to represent eight RG57-defined genotypes and their range of geographic origins), a band of $1.25 \mathrm{~kb}$ was detected in the PCR assay (as expected for A1 strains), whereas control amplifications with DNA from A2 strains showed no amplification. This supported the conclusion that the isolates tested were of the A1 mating type.

The results of DNA fingerprinting analysis were also consistent with this conclusion; the majority of the isolates were found to belong to EC-1 or US-1, lineages known to have the A1 mating type. None of the isolates showed the DNA fingerprints characteristic of A2 lineages known to occur in Argentina (BR-1), Bolivia (BR-1), Ecuador (EC-2), or the United States (US-7 and US-8).

Analysis of virulence and fungicide resistance. A set of 95 isolates was tested for virulence on a set of 11 potato lines carrying known resistance genes (differentials). Lineages EC-1 and PE-3 showed broad-spectrum virulence, attacking an average of 7.4
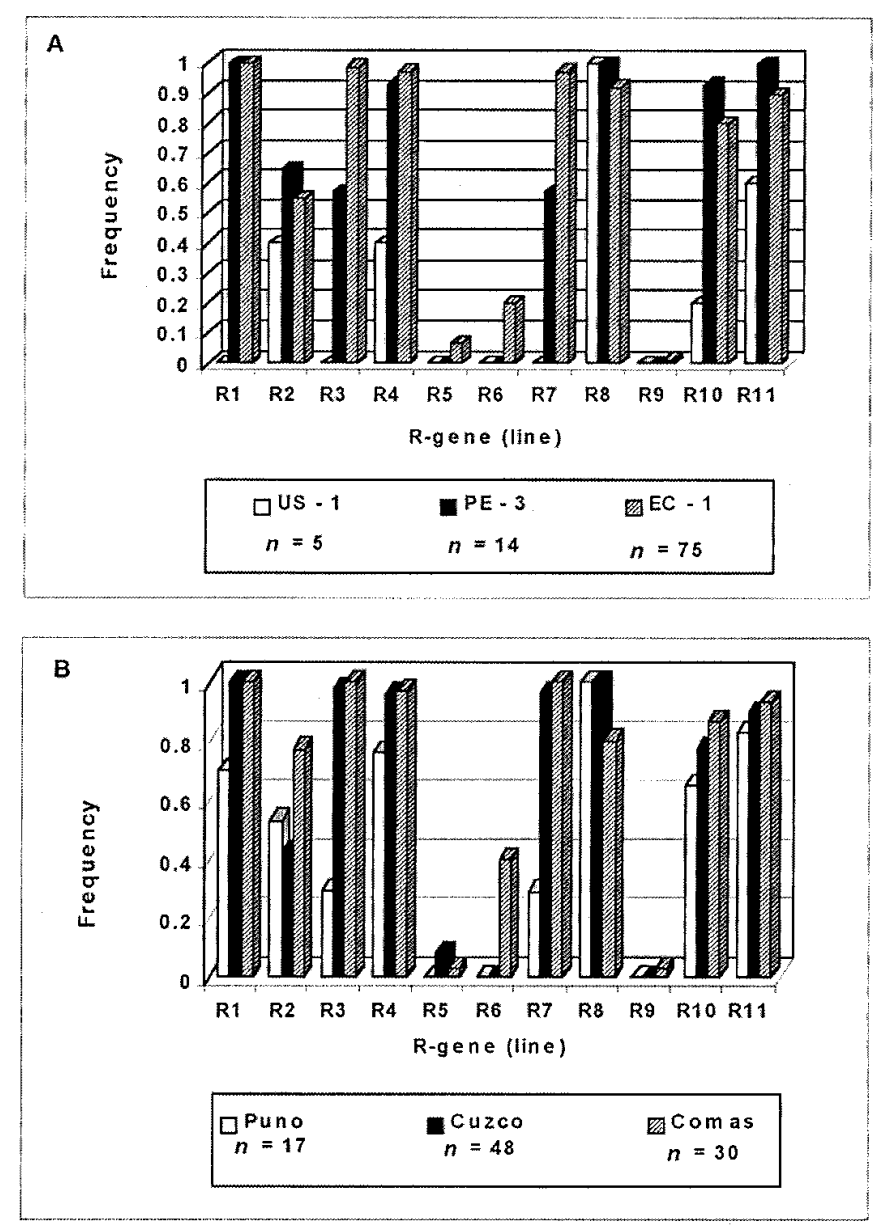

Fig. 5. Frequency distributions of virulences of Phytophthora infestans isolates collected in 1997 to 1999 to differential potato genotypes, graphed by $\mathbf{A}$, lineage and $\mathbf{B}$, department of origin. and 6.6, respectively, of the 11 differentials tested. Isolates of US-1 showed relatively narrow-spectrum virulence, attacking an average of 2.2 of the differentials (Fig. 5A). The virulence frequencies varied among the differentials used. For instance, most isolates were compatible with differentials carrying R1, R4, R8, $\mathrm{R} 10$, and R11. Few isolates could infect the lines carrying R5 or R6, and none could consistently cause sporulating lesions on the R9 line (Fig. 5B).

None of the 30 isolates from Junin that were collected in 1997 and analyzed for virulence overcame fewer than 4 of the $11 \mathrm{R}$ genes tested in this study. The majority of the isolates had virulence to 8 to $10 \mathrm{R}$ genes. This contrasts with results observed in the 1980s; 20 isolates collected in the department of Junin in 1984 and 1985 showed virulence to between 0 and 2 of the $10 \mathrm{R}$ genes tested, with the greatest number $(40 \%)$ showing virulence to none of the genes (41) (Fig. 6).

Pathotypic diversity of the overall collection was high (Nei's genetic diversity index $=0.80$ ). This diversity was widely distributed, with multiple races detected in most fields. The Gleason index $\left(H_{\mathrm{GR}}\right)$ for the overall collection analyzed was lower than the Shannon index $\left(H_{\mathrm{SR}}\right)$, indicating that richness was relatively low. Mean complexity (the number of virulence factors per isolate) by department varied from about four to nine. The department of Huanuco showed the highest virulence complexity means per isolate and per race. In all cases, $C_{i}$ exceeded $C_{p}$, indicating that the most common races were among the most complex (Table 3 ).

Most of the isolates $(n=322)$ were tested for sensitivity to the systemic fungicide metalaxyl. The majority of the isolates tested (84\%) were resistant. All isolates from Pasco, Junin, and Huanuco were fully resistant to metalaxyl. A few isolates from Cusco were moderately resistant or sensitive to the fungicide, whereas a greater proportion of the isolates from Puno were moderately resistant or sensitive. These trends corresponded to the distribution of pathogen lineages in the different departments. Most $(224 / 227=99 \%)$ of the EC-1 isolates tested were resistant to metalaxyl. Most $(19 / 33=58 \%)$ of the tested isolates of US-1 were sensitive to the fungicide, whereas 14 were resistant. The 59 tested isolates of PE-3 were divided among resistant $(n=30)$, moderately sensitive $(n=15)$, and sensitive $(n=14)$ (Table 4$)$.

Characteristics of lineage PE-3. The results of the phenotypic analyses reported above suggested that lineage PE-3 might be intermediate in phenotype between EC-1 (resistant to metalaxyl and broadly virulent) and US-1 (mostly sensitive to metalaxyl and with relatively few virulence factors). Marker data were used to assess the hypothesis that the PE-3 lineage could be derived from parasexual recombination events involving EC-1 and US-1. To determine the extent to which bands in PE-3 were shared with US-1 and EC-1, the following marker types were evaluated: RG57 bands, AFLP bands, allozyme markers, bands derived from amplification and digestion of mtDNA sequences, and bands derived from amplification and digestion of the $i p i B 1$ gene.

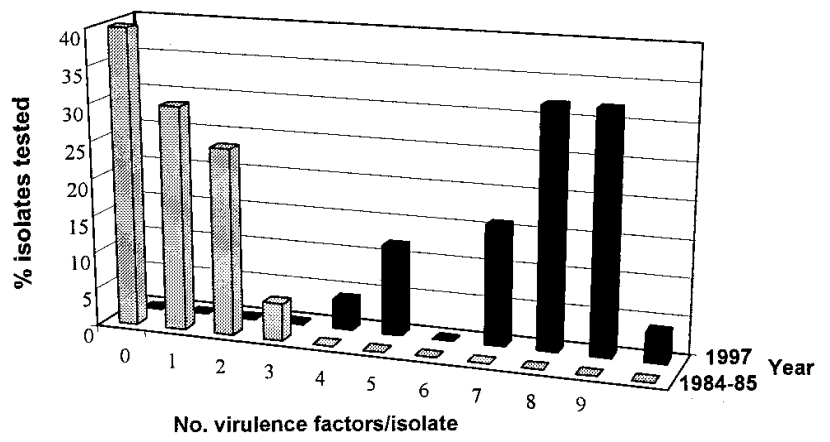

Fig. 6. Virulence spectra of isolates collected in Junin, Peru, comparing collections from 1984 to 1985 and 1997. Isolates were inoculated to the differential potato cultivars containing the known resistance genes R1 to R11. 
Analyses of mtDNA haplotypes and allozyme genotypes confirmed the identities of US-1 and EC-1, and indicated that PE-3 shared characters (i.e., band mobilities) with these lineages (Table 5). As expected, US-1 had mtDNA haplotype Ib and EC-1 had IIa $(8,12)$. PE-3 was found to have mitochondrial haplotype Ia, which shares one band each with EC-1 and US-1. Whereas isolates of US-1 had the Gpi genotype $86 / 100$ and isolates of EC-1 had the Gpi genotype 90/100, isolates of PE-3 had the Gpi genotype 100/100. Similarly, isolates of US-1 had the Pep genotype 92/100, isolates of EC-1 had the Pep genotype 96/100, and isolates of PE3 had the Pep genotype 100/100.

DNA band data were obtained for gene-based markers to evaluate the hypothesis that PE-3 was produced through parasexual recombination. Of the five genes assayed by PCR amplification and restriction digestion, four gave monomorphic banding patterns for US-1, EC-1, and PE-3. Polymorphisms were detected for the ipiB1 gene after digestion of the amplification products with Hae III (Fig. 7). The US-1 lineage ( $n=9$ isolates) had characteristic bands of 730 and $790 \mathrm{bp}$, whereas the EC-1 lineage $(n=$ 52 isolates) had characteristic bands of 430 and $440 \mathrm{bp}$. Lineage PE-3 ( $n=26$ isolates) shared one band of 500 bp with US-1, and another band of $520 \mathrm{bp}$ with EC-1.

Analysis of 32 polymorphic bands derived from RFLP and AFLP, however, indicated that PE-3 is unlikely to have been derived from recombination between US-1 and EC-1, at least from the particular genotypes examined in this study. Three of the sixteen polymorphic bands (19\%) present in PE-3 (isolate 1696) could not be attributed to either US-1 (isolate PPU13) or EC-1 (isolate PCZ116). Eight bands detected using the RG57 probe were polymorphic for the three lineages. Three of these were present in PE-3, two of these were also detected for EC-1, and one was not present in either US-1 or EC-1. Using AFLP (making only within-gel comparisons), 24 polymorphic bands were detected for the three lineages. Eleven of these were present in PE-3, and nine of these were shared with either US-1 or EC-1.

\section{DISCUSSION}

Based on DNA fingerprint analysis, we infer that populations of $P$. infestans in central Peru have changed dramatically since the mid-1980s. Although the pathogen populations in that region (Huanuco, Pasco, and Junin) were formerly of the US-1 lineage $(19,40)$, they are now dominated by the EC-1 lineage. EC-1 has been found to predominate $P$. infestans populations in Ecuador (9), and has also been detected in Colombia and Venezuela (10; G. Forbes, personal communication). Similar transformations have been seen in $P$. infestans populations in many countries in the 1980s and 1990s (11).

The sexual frontier, where the Peruvian A1 population was hypothesized to meet the Bolivian A2 population, was not found in this study. No evidence was found to suggest that the A2 population from Bolivia had reached Peru. The results of matingtype assays and PCR tests were consistent with the interpretation that the Peruvian isolates were uniformly of the A1 mating type. Instead, a "diversity frontier" was identified. Collections from
Pasco and Junin consisted only of EC-1, whereas in southern Peru, multiple pathogen lineages occurred in single fields. Collections from Cusco consisted of US-1, PE-3, and EC-1, whereas those from Puno consisted mostly of US-1 and PE-3. Interestingly, the only EC-1 isolates that were not fully metalaxyl resistant $(n=3)$ were found in Cusco and Puno, the regions where EC-1 was found in association with lineages showing susceptibility to the fungicide.

The spatial differentiation of $P$. infestans populations found in this study might be due to a progressive southward migration of the EC-1 lineage, which had not yet reached Cusco and Puno at the time of sampling. Alternatively, it might be that EC-1 is not as well adapted to the diverse host populations found in southern Peru. The spatial differentiation of Peruvian populations of $P$. infestans has practical implications. This differentiation should be taken into account when pathogen isolates are moved for experimental or other purposes. EC-1 was the only lineage detected at CIPs late blight screening sites, and the uniformity of pathogen populations at the two screening sites could be a concern. EC-1 has high virulence diversity and complexity and is widely distributed in the northern Andes, which make it well suited to screening. It might be worthwhile, however, to screen breeding materials at one site dominated by EC-1 and at another site with a more genetically diverse pathogen population.

The Peruvian collection described here was richer in pathogen diversity than that observed in Ecuador, with eight genotypes detected in the 1997 collections taken from Peru compared with three found in a roughly comparable collection from Ecuador. Among potato-infecting isolates collected in Ecuador between 1990 and 1993, 96\% were EC-1 (9), whereas 99\% of those

TABLE 4. Reaction to metalaxyl of isolates collected in five departments of Peru when grown on $10 \%$ V8 agar with varying levels of the fungicide ${ }^{\mathrm{a}}$

\begin{tabular}{lcccccc}
\hline Genotype & Reaction & Cusco & Puno & Pasco & Huanuco & Junin \\
\hline EC-1 & $\mathrm{R}$ & 96 & 1 & 45 & 7 & 75 \\
& MR & 1 & 0 & 0 & 0 & 0 \\
PE-3 & $\mathrm{S}$ & 1 & 1 & 0 & 0 & 0 \\
& $\mathrm{R}$ & 4 & 26 & 0 & 0 & 0 \\
& $\mathrm{MR}$ & 1 & 14 & 0 & 0 & 0 \\
US-1 & $\mathrm{S}$ & 3 & 11 & 0 & 0 & 0 \\
& $\mathrm{R}$ & 3 & 11 & 0 & 0 & 0 \\
& $\mathrm{MR}$ & 0 & 0 & 0 & 0 & 0 \\
PE-5 & $\mathrm{S}$ & 0 & 19 & 0 & 0 & 0 \\
& $\mathrm{R}$ & 1 & 0 & 0 & 0 & 0 \\
PE-6 & $\mathrm{MR}$ & 0 & 0 & 0 & 0 & 0 \\
& $\mathrm{~S}$ & 0 & 0 & 0 & 0 & 0 \\
& $\mathrm{R}$ & 2 & 0 & 0 & 0 & 0 \\
& $\mathrm{MR}$ & 0 & 0 & 0 & 0 & 0 \\
\hline
\end{tabular}

${ }^{a}$ Values represent the numbers of isolates with a given score. Isolates were considered resistant $(\mathrm{R})$ if colony growth was not reduced to less than $40 \%$ of the $0-\mathrm{ppm}$ control at any of the test concentrations $(0,5,50$, and $100 \mathrm{ppm})$. Isolates were considered moderately resistant (MR) if growth was reduced to $<40 \%$ of the control value at $100 \mathrm{ppm}$, but not at $5 \mathrm{ppm}$. Isolates were considered sensitive (S) if growth was retarded at $5 \mathrm{ppm}$ to $<40 \%$ of the 0-ppm control.

TABLE 3. Race diversity and complexity characteristics in Peruvian populations of Phytophthora infestans ${ }^{\mathrm{a}}$

\begin{tabular}{|c|c|c|c|c|c|c|c|c|c|}
\hline Place & $N_{p}$ & $N_{i}$ & $H_{G}$ & $H_{\mathrm{GR}}$ & $H_{S}$ & $H_{\mathrm{SR}}$ & $C_{i}$ & $C_{p}$ & $H$ \\
\hline Puno & 10 & 17 & 3.18 & 0.56 & 2.15 & 0.76 & 5.06 & 4.40 & 0.87 \\
\hline Cuzco & 16 & 48 & 3.87 & 0.32 & 2.12 & 0.55 & 7.10 & 6.80 & 0.81 \\
\hline Comas & 10 & 30 & 2.65 & 0.31 & 1.84 & 0.54 & 7.83 & 7.20 & 0.79 \\
\hline Peru, 1984b & 3 & 15 & 0.74 & 0.14 & 0.99 & 0.37 & 0.80 & 1.33 & $\ldots$ \\
\hline Peru, $1985^{\mathrm{b}}$ & 5 & 16 & 1.44 & 0.26 & 1.42 & 0.51 & 1.25 & 1.60 & $\ldots$ \\
\hline
\end{tabular}

${ }^{\mathrm{a}} N_{p}=$ number of races identified; $N_{i}=$ number of isolates tested; $H_{G}=$ Gleason index; $H_{S}=$ Shannon index; $H_{\mathrm{GR}}=$ relative Gleason index; $H_{\mathrm{SR}}=$ relative

Shannon index; $C_{i}=$ mean number of virulences per isolate; and $C_{p}=$ mean number of virulences per race.

${ }^{\mathrm{b}}$ Data of Tooley et al. (41). 
TABLE 5. Characteristics of Peruvian lineages of Phytophthora infestans identified in this study

\begin{tabular}{|c|c|c|c|c|c|}
\hline Genotype & $\mathrm{MT}^{\mathrm{a}}$ & RFLP fingerprint $^{\mathrm{b}}$ & $\mathrm{MtDNA}^{\mathrm{c}}$ & $G p i^{\mathrm{d}}$ & $P e p^{\mathrm{d}}$ \\
\hline EC-1 & A1 $(n=229)$ & $111010100100110100011101100101(n=229)$ & IIa $(n=52)$ & $90 / 100(n=52)$ & $96 / 100(n=52)$ \\
\hline PE-3 & $\mathrm{A} 1(n=62)$ & $110010000100110010011101100100(n=62)$ & $\mathrm{Ia}(n=26)$ & $100 / 100(n=26)$ & $100 / 100(n=26)$ \\
\hline US-1 & $\mathrm{A} 1(n=33)$ & $101010101100110100011001100100(n=34)$ & $\mathrm{Ib}(n=9)$ & $86 / 100(n=9)$ & $92 / 100(n=9)$ \\
\hline PE-5 & $\mathrm{A} 1(n=1)$ & $111010100100110100011000000100(n=1)$ & $\mathrm{IIa}(n=1)$ & $90 / 100(n=1)$ & $96 / 100(n=1)$ \\
\hline PE-6 & $\mathrm{A} 1(n=2)$ & $111010100000110100011100000101(n=2)$ & $\mathrm{IIa}(n=1)$ & $90 / 100(n=1)$ & $96 / 100(n=1)$ \\
\hline
\end{tabular}

a Mating type inferred from pairings with two isolates of the A1 mating type.

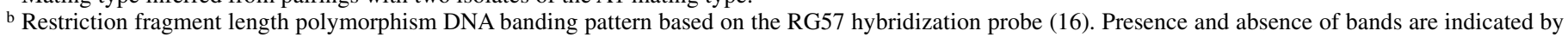
1 and 0 , respectively. From left to right, the bands refer to band positions 1 to 25, followed by band positions $1 \mathrm{~b}, 8 \mathrm{a}, 14 \mathrm{a}, 20 \mathrm{a}$, and 24a (9,16).

c Mitochondrial DNA haplotype (20).

d Allozyme genotypes at the glucose-6-phosphate isomerase (Gpi) and peptidase (Pep) loci.

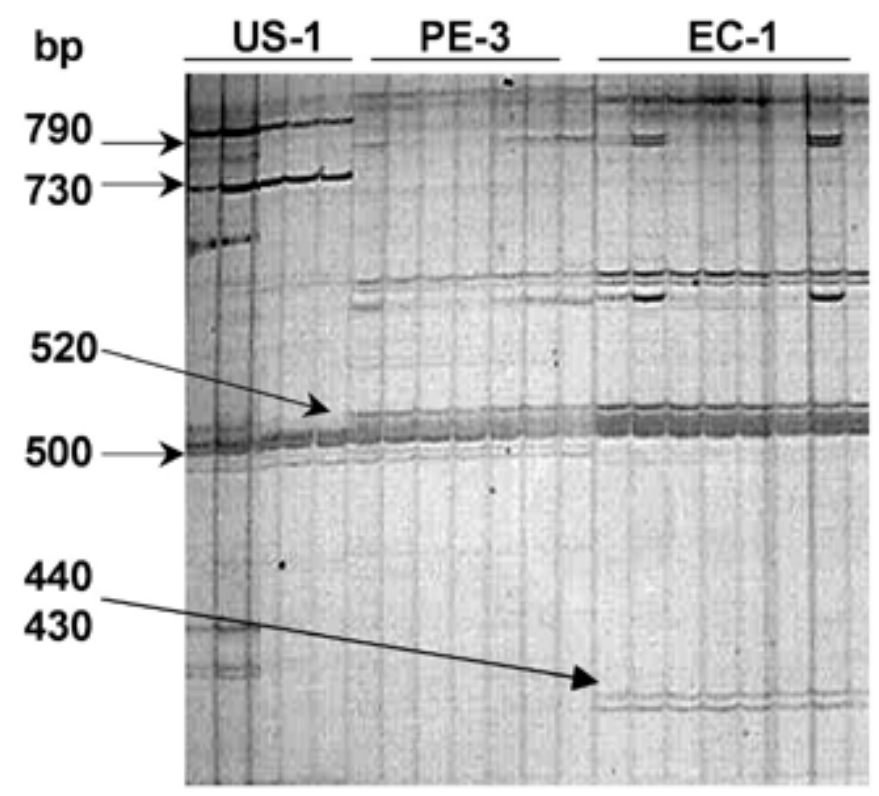

Fig. 7. Polymorphism among US-1, PE-3, and EC-1 detected by the polymerase chain reaction-based ipiB1/HaeIII marker.

collected from central Peru in the present study were EC-1. Among isolates from Cuzco and Puno, EC-1 accounted for 87.5 and $2 \%$ of isolates, respectively.

Although a moderate level of diversity was observed in southern Peru, the population structure was apparently clonal. The RG57 bands present in the Peruvian collection were all present in the database established by Forbes et al. (10). Some of these alleles had been detected in isolates from Japan and the Netherlands.

The lineage PE-3 is described here for the first time. Isolates of this lineage were detected among the few older Peruvian isolates (collected between 1994 to 1995) available for comparison with the present collection. The older collection may allow some sketchy insights into the shifts that have taken place in the Peruvian pathogen population. Of the three isolates collected from the department of Junin in the 1980s, all were US-1. Among the three isolates taken from Junin in 1994, two were PE-3 and one was EC-1. Among the 75 isolates taken from Junin in 1997, all were EC-1. It appears that the EC-1 lineage is gradually moving southward, replacing the US-1 lineage.

PE-3 appears to be associated with the interface between EC-1 and US-1. Marker data were analyzed to test the hypothesis that PE-3 is the result of recombination events involving EC-1 and US-1. It has been demonstrated in vitro that the parasexual cycle exists, and this process may also occur in nature $(14,30)$. Parasexual events are mentioned among the principal causes generating variability in asexual populations. The results reported here were ambiguous. Data on virulence and metalaxyl sensitivity, allozyme, mitochondrial markers, and ipiB1-related bands sug- gested that PE-3 might have been produced through recombination events between US-1 and EC-1. However, RFLP and AFLP marker data inconsistent with this hypothesis were also obtained.

It is possible that PE-3 originated from mutation or recombination events involving strains other than those assessed here. Characterization of Phytophthora collections taken from wild Solanum spp. in the Andes has led to the identification of further diversity, both at the lineage and genotype levels (34; G. Garry, CIP, personal communication). Sequence analysis is in progress to test the specific hypothesis that the mitochondrial genotype of PE-3 was derived from recombination.

US-1, the lineage that was until recently found worldwide $(2,15)$, was previously found to be predominant in Peru (41). This lineage has been considered responsible for the Irish potato famine $(11,15)$. Three genotypes of US-1 were detected in this study, bringing the total number of US-1 genotypes reported in Peruvian collections to six $(11,18,19)$. This relatively high proportion of the global total (eight US-1 genotypes were reported in the 1997 version of the global P. infestans marker database, three of which had been found in Peru) (10) could be considered consistent with the hypothesis that US-1 has been present in Peru for a relatively long period.

However, a recent study has challenged the view that US-1 was the only lineage involved in the late blight epidemics that caused the Irish potato famine. Ristaino et al. (37) recently analyzed the sequences of an mtDNA fragment from Irish famine-era specimens, obtaining unexpected results. The fragments show the sequence expected for the Ia mtDNA haplotype rather than the Ibtype characteristic of the US-1 lineage. PE-3, which has the Ia mtDNA haplotype and which coexists with US-1 in southern Peru, is of obvious interest in this light. Future studies will show whether this lineage and mtDNA haplotype were present in Ireland at the time of the famine.

\section{ACKNOWLEDGMENTS}

This work was supported in part by the Global Initiative on Late Blight (GILB) through funding provided by the Danish International Development Assistance (DANIDA). We thank E. de la Torre, F. Ventura, and J. Paredes for excellent technical support; R. Hijmans of CIP for providing suggestions on sampling routes based on geographic analysis of late blight risk factors; L. Palomino of INIA-Cuzco and E. Barahona of INIA-Puno for generous support and collaboration during the collection of isolates from Cuzco and Puno, respectively; W. Fry of Cornell University, for providing the clone RG57 DNA from isolates of known genotype and some older Peruvian isolates; G. Forbes of CIPQuito for providing mycelium of isolates from Ecuador; and $\mathrm{L}$. Turkensteen, of the Research Institute for Plant Protection, Wageningen, the Netherlands, and J. Duncan of the Scottish Crop Research Institute, Dundee, Scotland, for providing differential sets.

\section{LITERATURE CITED}

1. Abad, Z. G., and Abad, J. A. 1997. Another look at the origin of late blight of potatoes, tomatoes, and pear melon in the Andes of South America. Plant Dis. 81:682-688. 
2. Andrivon, D. 1994. Race structure and dynamics in populations of Phytophthora infestans. Can. J. Bot. 72:1681-1687.

3. Andrivon, D. 1996. The origin of Phytophthora infestans populations present in Europe in the 1840s: A critical review of historical and scientific evidence. Plant Pathol. 45:1027-1035.

4. Andrivon, D., and de Vallavieille-Pope, C. 1993. Racial diversity and complexity in regional populations of Erysiphe graminis f. sp. hordei in France over a 5-year period. Plant Pathol. 42:443-464.

5. Dagget, S. S., Götz, E., and Therrien, C. D. 1993. Phenotypic changes in populations of Phytophthora infestans from eastern Germany. Phytopathology 83:319-323.

6. De Paulo, J. J., and Powell, C. A. 1995. Extraction of double-stranded RNA from plants tissues without the use of organic solvents. Plant Dis. 79:246-248.

7. Dice, L. R. 1945. Measures of the amount of ecological association between species. Ecology 26:297-302.

8. Erselius, L. J., Hohl, H. R., Ordoñez, M. E., Oyarzun, P. J., Jarrin, F., Velasco, A., Ramon, M. P., and. Forbes, G. A. 1999. Genetic diversity among isolates of Phytophthora infestans from various hosts in Ecuador. Pages 39-48 in: Impact on a Changing World: Program Report, 1997-98. International Potato Center (CIP), Lima, Peru.

9. Forbes, G. A., Escobar, X. C., Ayala, C. C., Revelo, J., Ordoñez, M. E., Fry, B. A., Doucett, K., and Fry, W. E. 1997. Population genetic structure of Phytophthora infestans in Ecuador. Phytopathology 87:375-380.

10. Forbes, G. A., Goodwin, S. B., Drenth, A., Oyarzun, P., Ordoñez, M. E., and Fry, W. E. 1998. A global marker database for Phytophthora infestans. Plant Dis. 82:811-818.

11. Fry, W. E., Goodwin, S. B., Dyer, A. T., Matuszak, J. M., Drenth, A., Tooley, P. W., Sujkowski, L. S., Koh, Y. J., Cohen, B. A., Spielman, L. J., Deahl, K. L., and Inglis, D. A. 1993. Historical and recent migrations of Phytophthora infestans: Chronology, pathways, and implications. Plant Dis. 77:653-661.

12. Gavino, P. D. 1999. Mitochondrial DNA evolution and its utility for population genetic studies of Phytophthora infestans. Ph.D. thesis. Cornell University, Ithaca, NY.

13. Goodwin, S. B. 1989. DNA polymorphism in Phytophthora infestans: The Cornell experience. Pages 256-271 in: Phytophthora. J. A. Lucas, R. C. Shattock, D. S. Shaw, and L. R. Cooke, eds. Symp. Br. Mycol. Soc., Br. Soc. Plant Pathol., Soc. Irish Plant Pathol., Dublin.

14. Goodwin, S. B. 1997. The population genetics of Phytophthora. Phytopathology 87:462-473.

15. Goodwin, S. B., Cohen, B. A., and Fry, W. E. 1994. Panglobal distribution of a single clonal lineage of the Irish potato famine fungus. Proc. Natl. Acad. Sci. USA 91:11591-11595.

16. Goodwin, S., Drenth, A., and Fry, W. E. 1992. Cloning and genetic analyses of two highly polymorphic, moderately repetitive nuclear DNAs from Phytophthora infestans. Curr. Genet. 22:107-115.

17. Goodwin, S. B., Schneider, R. E., and Fry, W. E. 1995. Use of celluloseacetate electrophoresis for rapid identification of allozyme genotypes of Phytophthora infestans. Plant Dis. 79:1181-1185.

18. Goodwin, S. B., Smart, C. D., Sandrock, R. W., Deahl, K. L., Punja, Z. K., and Fry, W. E. 1998. Genetic change within populations of Phytophthora infestans in the United States and Canada during 1994 to 1996: Role of migration and recombination. Phytopathology 88:939949.

19. Goodwin, S. B., Sujkowski, L. S., and Fry, W. E. 1995. Rapid evolution of pathogenicity within clonal lineages of the potato late blight disease fungus. Phytopathology 85:669-676.

20. Griffith, G. W., and Shaw, D. S. 1998. Polymorphisms in Phytophthora infestans: Four mitochondrial haplotypes are detected after PCR amplification of DNA from pure cultures or from host lesions. Appl. Environ. Microbiol. 64:4007-4014.

21. Groth, J. V., and Roelfs, A. P. 1987. The concept and measurement of phenotypic diversity in Puccinia graminis on wheat. Phytopathology 77:1395-1399.

22. Groves, C. T., and Ristaino, J. B. 2000. Commercial fungicide formulations induce in vitro oospore formation and phenotypic change in mating type in Phytophthora infestans. Phytopathology 90:12011208 .

23. Hawkes, J. G. 1958. Significance of wild species and primitive forms for potato breeding. Euphytica 7:257-270.

24. Hawkes, J. G. 1978. History of the potato. Pages 1-14 in: The Potato Crop, the Scientific Basis for Improvement. P. M. Harris, ed. Chapman and Hall, London.
25. Judelson, H. S. 1996. Chromosomal heteromorphism linked to the mating type locus of the oomycete Phytophthora infestans. Mol. Gen. Genet. 252:155-161.

26. Kamoun, S., van der Lee, T., van den Berg-Velthuis, G., de Groot, K., and Govers, F. 1998. Loss of production of the elicitor protein INF1 in the clonal lineage US-1 of Phytophthora infestans. Phytopathology 88:1315-1323

27. Kamoun, S., van West, P., de Jong, A. J., de Groot, K. E., Vleeshouwers, V. G. A. A., and Govers, F. 1997. A gene encoding a protein elicitor of Phytophthora infestans is down-regulated during infection of potato. Mol. Plant-Microbe Interact. 10:13-20.

28. Koh, Y. J., Goodwin, S. B., Dyer, A. T., Cohen, B. A., Ogoshi, A., Sato, N., and Fry, W. E. 1994. Migrations and displacements of Phytophthora infestans populations in east Asian countries. Phytopathology 84:922927.

29. Kolmer, J. A. 1991. Phenotypic diversity in two populations of Puccinia recondita f. sp. tritici in Canada during 1931-1987. Phytopathology 81:311-315

30. Leach, S. S., and Rich, A. E. 1969. The possible role of parasexuality and cytoplasmic variation in race differentiation in Phytophthora infestans. Phytopathology 59:1360-1365.

31. Lebeda, A. 1982. Measurement of genetic diversity of virulence in populations of phytopathogenic fungi. Z. Pflanzenkr. Pflanzenschutz 89:88-95.

32. Nei, M. 1973. Analysis of the gene diversity in subdivided populations. Proc. Natl. Acad. Sci. 70:3321-3323.

33. Ochoa, C. 1954. Northern Peru, a possible new source of potatoes resistant to Phytophthora infestans. Am. Potato J. 31:371.

34. Ordoñez, M. E., Hohl, H. R., Velasco, J. A., Ramon, M. P., Oyarzun, P. J., Smart, C. D., Fry, W. E., Forbes, G. A., and Erselius, L. J. 2000. A novel population of Phytophthora, similar to P. infestans, attacks wild Solanum species in Ecuador. Phytopathology 90:197-202.

35. Pieterse, C. M., van't Klooster, J., van den Berg-Velthuis, G. C., and Govers, F. 1995. NiaA, the structural nitrate reductase gene of Phytophthora infestans: Isolation, characterization and expression analysis in Aspergillus nidulans. Curr. Genet. 27:359-366.

36. Pieterse, C. M., Verbakel, H. M., Spaans, J. H., Davidse, L. C., and Govers, F. 1993. Increased expression of the calmodulin gene of the late blight fungus Phytophthora infestans during pathogenesis on potato. Mol. Plant-Microbe Interact. 6:164-172.

37. Ristaino, J. B., Groves, C. T., and Parra, G. R. 2001. PCR amplification of the Irish potato famine pathogen from historic specimens. Nature 411:695-697.

38. Sanders, H. L. 1968. Marine benthic diversity: A comparative study. Am. Nat. 102:243-282.

39. Spielman, L., Sweigard, J. A., Shattock, R. C., and Fry, W. E. 1990. The genetics of Phytophthora infestans: Segregation of allozyme markers in $\mathrm{F}_{2}$ and backcross progeny and the inheritance of virulence against potato resistance genes R2 and R4 in $F_{1}$ progeny. Exp. Mycol. 14:57-69.

40. Therrien, C. D., Tooley, P. W., Spielman, L. J., Fry, W. E., Ritch, D. L., and Shelly, S. E. 1993. Nuclear DNA content, alloyzme phenotypes and metalaxyl sensitivity of Phytophthora infestans from Japan. Mycol. Res. 97:945-950.

41. Tooley, P. W., Therrien, C. D., and Ritch, D. L. 1989. Mating type, race composition, nuclear DNA content, and isozyme analysis of Peruvian isolates of Phytophthora infestans. Phytopathology 79:478-481.

42. Van der Lee, T., De Witte, I., Drenth, A., Alfonso, C., and Govers, F. 1997. AFLP linkage map of the oomycete Phytophthora infestans. Fungal Gen. Biol. 21:278-291.

43. Van West, P. 2000. Molecular tools to unravel the role of genes from Phytophthora infestans. Ph.D. thesis. Wageningen University, the Netherlands.

44. Van West, P., Kamoun, S., van't Klooster, J. W., and Govers, F. 1999. Ricl, a stress induced gene of the potato late blight pathogen Phytophthora infestans. Curr. Genet. 36:310-315.

45. Vega-Sánchez, M. E., Erselius, L. J., Rodriguez, A. M., Bastidas, O., Hohl, H. R., Ojiambo, P. S., Mukalazi, J., Vermeulen, T., Fry, W. E., and Forbes, G. A. 2000. Host adaptation to potato and tomato within the US1 clonal lineage of Phytophthora infestans in Uganda and Kenya. Plant Pathol. 40:1-10.

46. Wolfe, M. S., and Finckh, M. R. 1997. Diversity of host resistance within the crop: Effects on host, pathogen and disease. Pages 378-400 in: Plant Resistance to Fungal Diseases. H. Hartleb, R. Heitefuss, and H. H. Hoppe, eds. G. Fisher Verlag, Jena. 